\title{
DRUŽINSKE PRAKSE V POZNEJŠIH LETIH KOT IZZIV ZA UČENJE IN RAZISKOVANJE
}

\section{POVZETEK}

S spreminjanjem oblik družine in daljšanjem življenjske dobe nastajajo nove družinske prakse v poznejših letih. Vzpostavljajo se drugačne vloge starejših in drugačni medgeneracijski odnosi. Spremenjene družinske načine življenja raziskujemo z. različnimi metodami in interpretiramo v okviru različnih teorij. Ena od pogosteje uporabljenih je poststrukturalistična teorija prakse in model skupnosti prakse, ki je primeren za interpretacijo učenja kot sprejemanja kulturnih vzorcev in razvijanja novega znanja ter identitete. $V$ članku je razčlenjena povezava med spreminjanjem družinskih praks, različnimi odnosi in raziskovanjem učenja $v$ vsakdanjem življenju. Avtorica sklene z ugotovitvijo, da so novi partnerski in medgeneracijski odnosi $v$ družinah starejših izziv tako za refleksivno učenje kot tudi za raziskovanje.

Ključne besede: družina, teorija prakse, staranje, učenje, raziskovanje.

\section{FAMILY PRACTICES IN LATER LIFE AS A CHALLENGE FOR LEARNING AND RESEARCH - ABSTRACT}

Changes in family types and prolongation of life span are resulting in new family practices in later life. Older people are developing new roles and new types of intergenerational relations are emerging. The changed family ways of life are being researched with various methods and interpreted by means of various theories.

One of the more frequently used tools is the post-structuralist practice theory and the community practice model, which is appropriate for interpretation of learning as reception of cultural patterns and development of new knowledge and identity. The article presents an analysis of the connections between the changing patterns of family practices, various relationships and research into learning in everyday life. The author's conclusion is that the new partnership and intergenerational relations in older people's families represent a challenge for reflexive learning and research.

Keywords: family, practice theory, ageing, learning, research.

\section{UVOD}

Družine v srednjih in poznejših letih (midlife and later life families) so tiste, ki so prešle obdobje vzgoje otrok. Otroci so že odrasli, družinsko skupnost so zapustili ali jo zapuščajo. V literaturi smo v 80. in 90. letih prejšnjega stoletja včasih še srečevali razprave o teh dveh skupinah družin skupaj (prim. Arcus, Schvaneveldt, Moss, 1993; L'Abate, 1994), v sodobnosti pa se pojavljajo razprave o družinah $v$ poznejših letih ločeno od preostalih obdobij družinskega poteka. To obdobje prinaša drugačne izzive kot doba t. i. poznih srednjih let. Družina v srednjih letih se srečuje s fenomenom praznega gnezda in priprave na upokojitev. Družina v poznejših letih pa je navadno sestavljena iz dveh članov, ki sta že oba upokojena in si življenje organizirata $\mathrm{v}$ novih socialnih omrežjih ter $\mathrm{z}$ novimi cilji in željami.

Družinski načini življenja se v poznejših letih spreminjajo. Na to vpliva več dejavnikov, med katerimi sta dva izrazitejša. Prvi dejavnik je podaljševanje življenjske dobe. Ljudje doživijo višjo starost. Drugi dejavnik je spreminjanje družine, ki ustvarja nove povezave. 
Za preteklost sta bili značilni višja rodnost in krajša pričakovana življenjska doba, zato so bile družine skupine $\mathrm{z}$ več otroki in malo starimi ljudmi. To pomeni, da je v družini živelo manj generacij hkrati. Sodobne družine so t. i.

Družinski načini življenja se v poznejših letih spreminjajo. beanpole families. To pomeni, da so dolge in tanke kot prekle, kar je prispodoba za več zaporednih generacij, ki so maloštevilne. Uhlenberg (v Miller in Meredith, 2006) je za ZDA izračunal, da je imel posameznik pri 40 letih leta 190062 odstotkov možnosti, da je imel vsaj še enega od staršev. Leta 2000 je ta možnost narasla na 95 odstotkov.

$\mathrm{V}$ družinah se spletajo nove povezave in nastajajo nove odnosne dinamike, pojavljajo se nove vloge, ki jih v prejšnjih kulturnih razmerah nismo poznali. Ker imajo ljudje manj otrok, nastane novo obdobje »praznega gnezda «, ko so odrasli otroci odšli od doma in se lahko stari starši posvečajo vnukom, ne da bi imeli svoje mlajše otroke, kot se je to dogajalo, če je bilo v družini deset otrok. Vloga starega starša ne poteka vzporedno $\mathrm{z}$ vlogo starša in se zato razvija drugače. Če sta dedek in babica »osvobojena« svoje starševske vloge, ker so njuni otroci samostojni, bosta vzpostavila drugačen odnos do vnuka ali vnukinje, kot če bi sama še imela otroka podobne starosti, kot je vnuk ali vnukinja. Nova je tudi vloga starajočih se otrok, ki skrbijo za svoje ostarele in pomoči potrebne starše. Vse te nove vloge implicirajo tudi nove zmožnosti, da lahko ljudje svoje vloge čim bolj kakovostno oblikujejo v sodelovanju z drugimi.

Na nove družinske prakse vplivajo tudi spremembe v posamezni družini. Ker ljudje dlje živijo, bi lahko pričakovali, da bodo odnosi dolgotrajnejši, vendar to ni nujno. Odnosi se zdaj pretrgajo z ločitvami, odhodi, migracijami. Pogoste so ločitve v obdobju, ko otroci odrastejo. Vzpostavijo se novi odnosi, ker se odrasli otroci povežejo z novimi partnerji.
Naj to ponazorimo s primerom življenjske zgodbe starejšega para.

Jolanda in Jože sta stara 71 in 78 let, poročena sta 50 let in sta do pred 10 leti sledila običajnemu družinskemu loku. Po poroki sta imela dva otroka, ki sta se nato poročila in imela otroke. Pred 10 leti se je proi sin razvezal in vzpostavil novo partnerstvo $z$ razvezano žensko, ki ima dva otroka iz prvega zakona. Za Jožeta in Jolando je to pomenilo, da sta postala tudi "socialna stara starša dvema novima vnukoma. Njuna »biološka« vnuka živita s svojo mamo, ki ne želi imeti več stikov z Jolando in Jožetom, a tega ne brani vnukoma. Stiki med (skoraj odraslima) vnukoma in starima staršema se bolj ali manj ohranjajo prek internetnih povezav, ker sta se vnuka po ločitvi staršev z mamo in očimom preselila v Nemčijo. Njuna hčerka, drugi otrok, je bila poročena. Ko je ovdovela, je nekaj časa živela sama,zdaj je v partnerskem odnosu z novo partnerico, za katero pravi, da je prijateljica. Jolanda ima še mamo, ki biva $v$ domu za starejše, kjer jo dneono obiskuje.

Strukture sodobnih družin so fluidne, dogodki nepredvidljivi, odnosi se nenehno vzpostavljajo. Ni družbeno sprejetih pravil, ki bi določali odnose. Govorimo o refleksivni družini, fluidni ljubezni. Nekateri avtorji (npr. Morgan, 2011; Gabb, 2010) predlagajo, da bi - prav zaradi poudarka na procesnosti in nepredvidljivosti - uporabljali oznako družinskost namesto samostalnika družina. Drugi predlagajo, da bi uporabljali oznako družine (v množini) ali družinska skupnost, kjer naj bi bil poudarek na skupnosti. Pridevnik družinska pa označuje vrsto skupnosti.

Podobno kot z oznako za družino je tudi z oznako za starost (old age), ki naj bi jo nadomeščali z besedo staranje (ageing), saj s tem poudarimo proces staranja, katerega začetki se 
kažejo že v odraslosti in ne šele z vstopom v poznejša leta. Tako bi se tudi izognili ostremu ločevanju med odraslostjo (včasih t. i. drugim obdobjem), ki naj bi bila povezana z delom, in t. i. tretjim življenjskim obdobjem. Poimenovanje za tretje življenjsko obdobje je nastalo v času, ko je bil prehod med delom in upokojitvijo bolj izrazit. Sodobni življenjski poteki pa so zelo raznoliki in jih ne moremo zajeti s poimenovanjem in razlikovanjem med drugim in tretjim življenjskim obdobjem. Zamenjava besed ni povezana le s poudarjanjem procesnosti in raznolikosti osebnih trajektorijev, temveč je povezana tudi z željo, da bi spremenili pojmovanje starosti. Slednje je pogosto osredotočeno na težavnost, zdravstvene probleme in je tako predmet medicinskega modela interpretacije staranja. Poleg medicinskega modela bi radi okrepili sociološke in psihološke ter gerontagoške modele, ki omogočajo interpretacije staranja tudi kot procesa osebnostnega razvoja, razvoja socialnih mrež posameznika, učenja v starosti ipd. in ne le upadanja telesne moči. V medicinskem modelu smo najpogosteje osredotočeni na potrebo po pomoči, v drugih modelih poudarjamo tudi druge odnose, ki so označeni z dialoškostjo, udeleženostjo, samostojnostjo.

S spreminjanjem družine se ukvarjajo različne vede. Njihova spoznanja lahko uporabljamo, ko raziskujemo družinske prakse in učenje. V okviru nastajajočih družinskih študij (family studies) opazimo raziskovalno zanimanje za odnose, prehode, socialne vloge, ki se razvijajo v starejših družinah, npr.:

- odnosi med ostarelimi starši in odraslimi otroki,

- odnosi med ostarelimi starši in ostarelimi otroki,

- odnosi med partnerji, ki že desetletja živijo skupaj (dolgotrajna partnerstva),

- odnosi med starajočimi se sorojenci/odnosi med brati in sestrami,

- odnosi med vnuki in starimi ter prastarimi starši,
- prehod v upokojitev,

- transformacije ob vdovstvu, ločitvi,

- novo vzpostavljanje partnerskih odnosov v starejših letih,

- oblikovanje socialnih mrež v lokalnem okolju,

- vključenost starejših v sorodstvene mreže ... Vsi omenjeni odnosi so povezani tudi z učenjem. Soustvarjanje odnosov v okoliščinah, kjer vzorci za podobne odnose še niso oblikovani, terja novo znanje ljudi.

\section{TEORIJA PRAKSE - MODEL ZA INTERPRETACIJO PONAVLJANIA IN POSTAJANJA}

Družine, ki se starajo, imajo izkušnjo skupnega bivanja in skupnega staranja, razvile so svojo mikrokulturo s pravili, vlogami in odnosi. Nič presenetljivega ni, če srečamo družine s štirimi generacijami, reorganizirane družine, kjer so v sistemu rodni stari starši in socialni stari starši, kot smo jih omenili v zgornjem primeru. Družinski odnosi nenehno nastajajo; družino »izdelujejo« člani družine v kulturnem okolju, kjer živijo, zato je treba razmišljati o soudeleženosti in soodgovornosti vseh za vse odnose. Tudi medgeneracijski odnosi nastajajo v sociokulturnem kontekstu in se povezujejo v vzorce delovanja, mišljenja, čutenja. Prepletenost med kulturnim okoljem in dejavno vlogo posameznika zajamejo $\mathrm{v}$ svojem modelu teorije prakse (practice theory), ki so prav zato pogosto uporabljene $\mathrm{v}$ interpretaciji družinskih potekov. Podobno kot smo zgoraj omenili pojmovni premik od starosti k staranju, se tudi pri opisovanju razvoja v družini uporablja koncept družinskega poteka namesto družinskega cikla, ki ga je oblikovala Evelyn Duvall kot prikaz zaporednih faz v razvoju družine. V sodobnih družinskih potekih ni jasne zaporednosti faz in tudi ni predvidljivih sosledij. Fluidnost in nepredvidljivost ustvarjata potrebo po nenehnem refleksivnem učenju in ustvarjalnem pristopu $\mathrm{k}$ odnosom. Zato ni naključje, da so se v zadnji tretjini prej- 
šnjega stoletja začeli uporabljati teoretični modeli, ki več pozornosti posvečajo delovalnosti (agency) v primerjavi z omejitveno strukturo, ki posameznika disciplinira. Ena od teh teorij je tudi teorija prakse, znotraj katere se je razvil model skupnosti prakse.

Družinski odnosi nenehno nastajajo.

Teorijo prakse je Postill (2010) označil kot poststrukturalistično socialno teorijo. Njen razvoj je povezan z zanimanjem za vsakdanjost in z deli de Certeauja, Foucaulta, Bourdieuja, Giddensa, Latoura. Teorija prakse išče srednjo pot med trditvijo, da je vsaka sprememba rezultat posameznikovega delovanja, in trditvijo, da je možno vsak fenomen pojasnjevati z vplivi strukture oziroma družbe kot celote. Avtorji so želeli osvoboditi delovalnost (agency), to je človekovo sposobnost, da deluje in spreminja svet, iz omejitev strukturalističnih in sistemskih modelov.

Prakse so »telesne in mentalne rutine « (Reckewitz, 2002). Nove rutine ali spremembe $\mathrm{v}$ rutinah nastajajo z učenjem. Praksa so načini vedênja, ki so sestavljeni iz različnih medsebojno povezanih elementov: telesne in mentalne aktivnosti, predmeti in njih uporaba, znanje, čustva, motivacija. Posameznik je nosilec prakse kot telesni in mentalni delovalec (agent). Praksa je torej rutiniziran način gibanja teles, upravljanja predmetov, obravnavanja subjektov, opisovanja in razumevanja sveta. Prakse tvorijo vzorce, ki reproducirajo določene načine porabe dobrin, ustvarjanja, vendar nobena praksa v razmerju do drugih praks ni zaprta, vsaka prenese inovacije, kar je povezano z učenjem.

O učenju v skupnosti prakse govorimo tedaj, ko se skupaj učijo ljudje, ki imajo skupen interes, ki sodelujejo ob skupnih problemih, prenašajo svoje znanje drugim in iščejo rešitve ter razvijajo novosti. Termin sta uporabila Lave in Wenger leta 1991, ko sta razvijala koncept situacijskega učenja na delu (Lave, 2010). V okviru teorije prakse lahko družino opazujemo kot skupnost prakse, ki se uči, oblikuje posameznikovo in skupno identiteto.
Učenje je za Wengerja (2010) del človekove participacije v svetu. Socialna participacija pomeni, da posameznik sodeluje v praksah ter v odnosu do skupnosti in prakse oblikuje svojo identiteto. Participirati v kuhanju dnevnih obrokov hrane ali pospravljanju stanovanja pomeni neko obliko aktivnosti in hkrati tudi obliko pripadanja. Participacija ne določa le tega, kaj delamo, temveč tudi to, kako svoje delovanje interpretiramo. Če družino analiziramo kot skupnost prakse, upoštevamo naslednje elemente: prakso, pomen, skupnost, identiteto. Upoštevamo, da se v skupni aktivnosti, ki je del vsakdanjega življenja, oblikuje individualna in skupna identiteta, gradijo skupni pomeni in občutek pripadanja. Ljudje se so-ustvarjajo ali so-vzgajajo v odnosih in delovanju.

\section{SPREMINIANJE IN REFLEKSIVNO UČENIE}

Sodeč po raziskavah iz 90. let (Finch in Mason, 1993), ljudje ne vstopajo v odnose nekritično in jih ne gradijo zgolj po pravilih kulture, ki jim je dana v okolju. O odnosih se dogovarjajo in interakcije oblikujejo. Pri »nastajanju scenarija « so tudi avtorji in ne le ponavljavci že vpisanih kulturnih vzorcev. Družinski odnosi so pojavljajoči, a hkrati nenehno nastajajo in niso zgolj ponavljajoči, čeprav tega ne moremo zanemariti. Mnogo raziskav kaže na ponavljanje vzorcev iz preteklih generacij. Da bi se izognili ponavljanju bolečih in neučinkovitih odnosnih in komunikacijskih vzorcev med moškimi in ženskami ter med generacijami, da bi razvijali družinsko prakso, pa potrebujemo refleksivno učenje. To potrebujemo tudi zato, da bi oblikovali nove odnose, kakršnih iz zakladnice preteklosti ne poznamo. Imamo torej dva izziva za učenje. Eden je, da se pojavljajo nove vloge, ki jih prej nismo poznali, drugi je, da se znane vloge destabilizirajo. Vsaka družina oblikuje svoje vloge in odnose ter za to potrebuje pristop, s katerim misli svojo prakso in jo inovativno spreminja. Takšno dogajanje zajamejo modeli biografskega učenja, 
narativnega učenja, izkustvenega učenja (prim. Biesta in drugi, 2011). Koncept družinske prakse, ki ga med raziskovalci družine uporabljata npr. Morgan (1996), Nelson (2006), upošteva vidike strukture in vidike delovalnosti. Tako s prepletom strukture in aktivnosti - pokažejo na nove družinske izkušnje in na novo učenje $\mathrm{v}$ družinskih odnosih.

Ljudje ustvarjajo svoje družine, iščoč ravnovesje med strukturo (pravila kulture) in delovalnostjo. Oblikujejo jih v vsakodnevnih rutinah: od prehranjevanja do gospodinjskih del, organizacije prostega časa ... Gradijo jih v vsakodnevni dinamiki odnosov. Učenje, ki se pri tem dogaja, razumemo kot:

a) procese pridobivanja novih znanj, veščin,

b) procese spreminjanja načinov pojmovanja, navad in

c) procese postajanja, ki se nanašajo na oblikovanje identitete.

Za učenje je pomembna dialektika med stabilnostjo in spremenljivostjo. Ta značilnost je povezana $\mathrm{z}$ dogodki ob prihajanju in odhajanju članov (spreminjanje strukture), s spreminjanjem vlog (odraščanje, staranje) in dogajanji zunaj družine, npr. spremembami na trgu dela, ekološkimi problemi, gospodarsko krizo. Omenjene značilnosti družinskih praks veljajo za družine v vseh starostnih obdobjih, čeprav so bile doslej raziskave bolj osredotočene na mlajše družine. Razvoj medgeneracijskih odnosov v družini, odnosov med spoloma, odnosov med krvno povezanimi in socialno povezanimi se dogaja $v$ daljših obdobjih in ustvarja zakladnico izkušenj, pojmovanj, načinov pojasnjevanja in vpliva na odnose v poznejših letih. O tem, kako se ti vplivi pokažejo, imamo še razmeroma malo vedenja.

\section{IZZIVI ZA DRUŽINSKE PRAKSE IN IZZIVI ZA RAZISKOVANIE}

$\mathrm{V}$ raziskavah o družini in družinskem učenju je bilo doslej več pozornosti posvečene tistim obdobjem družinskih potekov, ko se rojevajo otroci in se družinski člani spreminjajo/vzgajajo, ker v družino vstopajo novi člani. Tudi večina izobraževalnih programov je bila namenjena družinam v zgodnejših obdobjih, ko je izziv vzpostavljanje partnerstva in rojevanje otrok. A tudi družina v poznejših letih doživlja mnoge spremembe, le da raziskovalci do nedavnega niso bili pozorni do teh pojavov. $\mathrm{V}$ zadnjem desetletju pa nastajajo raziskave o parih $\mathrm{v}$ času prehoda $\mathrm{v}$ upokojitev (Bucheb-

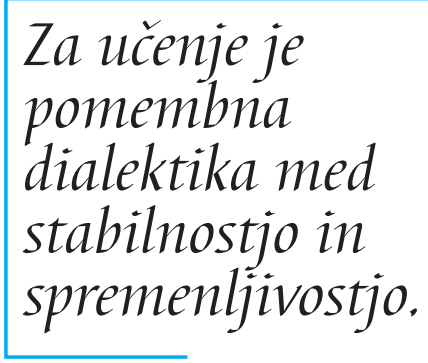
ner-Ferstl, 2005), odnosih med materami in odraslimi hčerami (Fisher, Miller-Day, 2006), učenju med starejšimi brati in sestrami (Ličen, 2006) in tudi o vplivu migracij, novih bolezni, selitev, večkulturnosti, soočanju z boleznijo in smrtjo. Slednje je še vedno tabuizirana tema in se je lotevamo razmeroma redko. Podobno je zanemarjena tema spolnega življenja pri starejših parih, še posebno pri istospolnih starejših parih. Raziskave kažejo, da niso družine starejših nič bolj determinirane kot družine mlajših generacij. Tudi v starosti ljudje konstruirajo svoje družinske odnose, se odločajo in bolj ali manj reflektirano ustvarjajo svoje dnevne prakse. Nekateri starejši imajo sicer manj možnosti za nadzorovanje svojih dnevnih praks, kar je povezano z onemoglostjo in boleznijo, vendar pa večina starejših ni nič bolj socialno ali ekonomsko odvisnih ali učljivih, kot so mlajše družine.

V nadaljevanju bomo omenili nekatere najpogostejše odnose, ki vplivajo na družinske prakse in jih tudi $\mathrm{v}$ raziskavah najpogosteje srečamo kot tiste, ki vplivajo na učenje v družinah.

Starejši in njihovi odrasli otroci - Ta odnos je pogosto zaznan kot odnos dajanja in prejemanja (pomoči). V resničnem življenju večina starejših ohrani razmeroma samostojno življenje, četudi v povezavi s svojimi otroki, ki se tudi že starajo. Nov trend se kaže v razmeroma daljših obdobjih skupnega/ločenega življenja (faze LAT). Znana je faza LAT, ko se mlajši odmika- 
jo od staršev in si postopoma organizirajo samostojno življenje. Druga faza LAT, ki je manj raziskana, nastopi v starosti, ko se ostareli starši približujejo svojim odraslim otrokom. Ostareli starši lahko živijo samostojno in potrebujejo razmeroma malo pomoči svojih otrok. Živijo v ločenih gospodinjstvih, a hkrati skupaj. Medgeneracijske povezave in izmenjave (informacij, odnosnih dobrin, materialnih dobrin) se spreminjajo in diferencirajo.

Tudi vloga starih staršev se spreminja. V strokovni literaturi srečamo vsaj pet različnih tipov odnosov med vnuki in starimi starši. Poleg bioloških vnukov je glede na spreminjanje družinskih vzorcev in kompleksne sorodstvene vzorce vedno več »socialnih" vnukov in odnosov s starimi starši (step-grandparents), to je odnosov z otroki, ki so »prišleki« v sorodstvenih povezavah. Taki odnosi postajajo izkušnja mnogih starejših, a še ni podrobneje raziskana kot izkušnja, ki oblikuje (prim. Allan in drugi, 2008).

Vedno več je partnerskih zvez, ki trajajo 40, 50 in več let. Intimne zveze v poznejših letih pa niso le heteroseksualne dolgotrajne zakonske zveze. Poleg teh obstajajo tudi istospolna partnerstva (o katerih nimamo raziskav), partnerstva, nastala v starejših letih, partnerstva, ki nastanejo po ločitvah ali vdovstvu. Ta partnerstva so različna, toda vsa tvorijo »odnosno dobrino« ali »socialni kapital«. Ker so to nove oblike, terjajo tudi nove zmožnosti, da bi jih lahko uresničevali. Dolgotrajni odnosi niso brezkonfliktni, oba partnerja se soočata s konflikti in jih morata reševati. Dolgotrajne zveze so prešle tudi različna tranzicijska obdobja, $\mathrm{v}$ katerih sta se oba spreminjala in oblikovala nove pomene. Obdobji transformativnega učenja sta denimo odhod otrok in upokojevanje. Upokojitev velja za pomembno tranzicijo v življenjskem poteku, vnese nova pravila pri delitvi del, organizaciji časa in razporeditvi denarja, zato je to faza intenzivnega učenja. Pri razmisleku o družinskih praksah in izkušnjah v poznejših letih ne moremo mimo do- živetja vdovstva. Izkušnja vdovstva bistveno vpliva na mnoge elemente $v$ vsakdanjem življenju, ob njej se posameznik identitetno spremeni. Včasih se poveča osamljenost, včasih se odnosi s sorodstvom in drugimi socialnimi mrežami izboljšajo. Pogosteje vdovstvo pomeni tveganje za osamljenost, zato bi potrebovali oblike spodbud, kot so svetovanja, podporne skupine, različne dejavnosti, ki posameznika vključijo v nove socialne mreže, če to želi.

Pojavljajo se tudi novi izzivi, povezani z medkulturno družbo, migracijami, globalizacijo, novo tehnologijo. Migracije ter nastajajoče večkulturne skupnosti in večkulturne družine so nova okolja za učenje. Včasih se starejši učijo tuje jezike, da bi se sporazumevali s svojimi snahami ali zeti in vnuki. Zanimiv fenomen so tudi negovalke, ki prihajajo iz ekonomsko manj razvitih držav. V Veliki Britaniji imajo veliko poljskih negovalk. Kot so v preteklosti slovenske ženske hodile za varuške otrok $\mathrm{v}$ tuje dežele, zdaj prihajajo tuje ženske (tudi v Slovenijo), da pomagajo pri negi starejših. Ženske, ki odidejo od doma, najpogosteje pustijo svoje otroke s svojimi starši. Stari starši skrbijo za vnuke, stari starši prevzamejo vlogo staršev. Starejši, ki potrebujejo pomoč, se srečajo z negovalko iz druge kulture.

Povezave starost - migracije so izziv tudi za migrante, ki se zdaj starajo v okolju, kamor so nekoč prišli. Raziskave v Franciji (Attias-Doufut, Tessier, Wolff v Segalan, 2009) kažejo, da se starejši migranti počutijo stabilno in ne nameravajo zapustiti Francije. O odhodu ne razmišljajo, ker imajo v Franciji odrasle otroke. Čeprav so upokojeni in jih delo ne veže, imajo občutek, da so integrirani v francosko družbo. Najbolje se počutijo tisti, katerih otroci so »napredovali « v srednji sloj.

\section{IZZIVI ZA RAZISKOVANJE}

Mnoge spremembe so vir za raziskovanje družinskega življenja in učenja. Zgoraj smo omenili nekatere vloge in odnose, ki so tak vir za učenje, a so še razmeroma malo raziskani. Iz- 
zivi se kažejo tudi na ravni raziskovalnih metod in zamolčanih tem. Raziskovalci so pred vprašanjem, kako se približati učenju v intimnih odnosih. Sprašujejo se o učinkovitosti raziskovalnih metod pri spoznavanju učenja v vsakdanjem življenju. Naj omenimo nekatere. Gabb (2010) v svojem delu predstavlja različne metode za raziskovanje zasebnega življenja, od preglednega anketiranja do zapisovanja intimnih zgodb z uporabo biografskih intervjujev. Različni avtorji se v zborniku (Floyd in Morman, 2006) osredotočajo na uporabo različnih metod za raziskovanje komunikacije v družinah. Poleg kvantitativno zastavljenih raziskav, ki vključujejo velike vzorce ljudi, se vedno bolj širijo kvalitativni pristopi, s katerimi raziskovalci spoznavajo življenjske svetove posameznikov in manjših skupin. Ti pristopi so pogosteje uporabljeni pri proučevanju vsakdanjega življenja in biografskega učenja. Uporaba biografske pripovedi (življenjske zgodbe) ima lahko dve funkciji. Biografijo lahko razumemo kot neke vrste ogledalo, ki odseva materialno-ekonomske, socialne in kulturne okoliščine življenja skupin v nekem času in prostoru. Za proučevanje učenja pa uporabimo življenjsko zgodbo kot sredstvo za premislek o igri strukture in delovalca.

Izziv je tudi raziskovanje prikritih tem, kot so kontroverznosti družinskega nasilja (prim. Loseke, Gelles, Cavanaugh, 2005). Kako spoznati in preprečevati prikrito nasilje nad starejšimi v družinah? Kako preprečevati zlorabe starejših v družinah? Ta in podobna vprašanja tudi kažejo na potrebo po dodatnem raziskovanju. Dobrodošle bi bile primerjalne študije o starejših družinah v različnih kulturah, ki bi sistematično prikazale kompleksnost staranja $\mathrm{v}$ družinskem okolju. Potrebovali bi tudi raziskave na večjih vzorcih v posameznih kulturah, saj je staranje $v$ različnih kulturah različno. Tako kot z obsežnimi nacionalnimi raziskavami spremljamo mladost in prehode $\mathrm{v}$ mladosti - ker je to novo obdobje -, bi bilo dobro, da bi spremljali tudi staranje in značilnosti življenja v starosti. Deloma to pri nas počnemo z razi- skavo Potrebe, zmožnosti in stališča starejših ljudi v Sloveniji (Ramovš, 2011).

V zahodni družbi nastaja nova skupina »novih starejših «, ki niso le posledica podaljševanja življenjske dobe. Novi načini življenja so tudi odraz socialne konstrukcije starosti. V sodobnem pojmovanju staranja in starosti, ki se razvija zadnjih 30 let, prevladuje zamisel dejavnega staranja. Dejavno staranje se ne kaže le na področju dela (čim poznejše upokojevanje), temveč tudi na področju izobraževanja, političnega delovanja, potovanj, prostovoljskega delovanja, spolnega življenja, prehranskih navad in tudi družinskega življenja. »Novi starejši« (ki so bili rojeni po drugi svetovni vojni in od katerih so bili nekateri del študentskih uporov iz leta 1968) cenijo dejavnost in čas kot sredstvo za razvoj individualnih zmožnosti, kar se kaže tudi v intimnem življenju in družinskih praksah. O njihovih družinskih praksah ne moremo presojati $\mathrm{z}$ zornega kota družinskih praks prejšnjih generacij, kar je še en element, ki kaže na potrebo po raziskovanju.

\section{LITERATURA}

Allan, G., Hawkler, S., Crow, G. (2008). Stepfamilies. London: Palgrave.

Arcus, M., Schvaneveldt, J. D., Moss, J. J. (ur.) (1993). Handbook of Family Life Education. Vol 1, Vol 2. Newbury Park, London, New Delhi: Sage.

Biesta, G., Field, J., Hodkinson, P., Macleod, F., Goodson, I. (2011). Improving Learning through the Lifecourse. London, New York: Routledge.

Buchner-Ferstel, S. (2005). Das Paar beim Übergang in den Ruhestand. Wien: Österreichisches Institut für Familienforschung.

Finch, J., Mason, J. (1993). Negotiating family responsibilities. London: Routledge.

Fischer, C., Miller-Day, M. (2006). »The Mother Adult Daughter Relationship«. V: Floyd, K., Morman, M. (ur.), Widening the Family Circle. London: Sage.

Gabb, J. (2010). Researching Intimacy in Families. New York: Palgrave MacMillan.

Lave, J. (2010). »The practice of learning«. V: Illeris, $\mathrm{K}$. (ur.), Contemporary theories of learning. London, New York: Routledge. 
L'Abate, L. (1994). Family Evaluation. Thousand Oaks: Sage.

Ličen, N. (2006). »Odnosi med odraslimi brati in sestrami kot polje naključnega in priložnostnega učenja«. Andragoška spoznanja, 2: 57-66.

Loseke, R. D., Gelles, R. J., Cavanaugh, M. M. (ur.) (2005). Current Controversies on Family Violence. London: Sage.

Miller, R. B., Meredith, W. H. (2006). »Diversity in International Aging Families «. V: Ingoldsby, B. B., Smith, S., D. (ur.), Families in Global and Multicultural Perspective. Thousand Oaks, London, New Delhi: Sage.

Morgan, D. (1996). Family Connections. Cambridge: Polity.

Morgan, D. (2011). Rethinking Family Practices. New York: Palgrave MacMillan.

Nelson, M. (2006). »Single Mothers »do« Family«. Journal of Marriage and the Family, vol. 68: 781795.

Postill, J. (2010). »Introduction: Theorising media and practice«. V: Bräuchler, B., Postill, J. (ur.), Theorising media and practice. Oxford, New York: Berghahn.

Ramovš, J. (2011). »Potrebe, zmožnosti in stališča starejših ljudi v Sloveniji«. Kakovostna starost, 2: 3-21.

Reckwitz, A. (2002). »Toward a Theory of Social Practices «. European Journal of Social Theory, 2: 243-263.

Segalan, M. (2009). Sociologija porodice. Beograd: Clio.

Wenger, E. (2010). »A social theory of learning«. V: Illeris, K. (ur.), Contemporary theories of learning. London, New York: Routledge. 